\title{
Towards a system of integrated policies to deal with the urban sprawl areas in large Egyptian cities
}

\author{
Mahmoud Fouad Mahmoud ${ }^{1}$ \\ ${ }^{1}$ Associate Professor, Faculty of Engineering \\ Suez Canal University, Ismailia, Egypt. \\ mafouad66@hotmail.com
}

\begin{abstract}
Urban sprawl is considered a global phenomenon, though it varies in its severity from one country to another. This phenomenon reflects positive effects on life and development, but at the same time, it reflects a negative impact on various economic and social aspects.

In the Arab Republic of Egypt, the population pressure on the urban centers during the past years led to an increase in the urban sprawl areas towards the agricultural land that surround cities, which devoured more than 1.5 million acres for the urban and rural extensions until now, and still devour more than 60 thousand acres per year.

The study discusses the absence of an integrated system that deals with the urban sprawl areas in the preparation project of the urban strategic plans for cities, which leads to the neglect and lack of implementation of the detailed plans for these areas.

This study addresses the concept of urban sprawl phenomenon, and its most important problems at the global, Arab and local levels. The first part discusses the problem of urban sprawl areas in the Egyptian cities, and presents an analytical study of some of the Large Egyptian cities (more than 100 thousand people), which indicates the most important features of the urban Structure of the Egyptian cities, the most important attraction factors and trends of urban sprawl. And this part discusses the most important consequences resulting from the urban sprawl of the Egyptian cities, The second part discusses the reality of urban sprawl and its sustainability in the national strategic plans project of the Egyptian cities in terms of challenges and opportunities to deal with.

The study concluded to propose a vision for the formulation of integrated policies, at the national, regional and local levels, to deal with the urban sprawl areas in the Large Egyptian cities (more than 100 thousand people) within the framework of the preparation of general and detailed strategic plans of the Egyptian cities.
\end{abstract}

Key words: Urban sprawl, urbanization, urban growth, the protection of agricultural land, Egyptian cities.

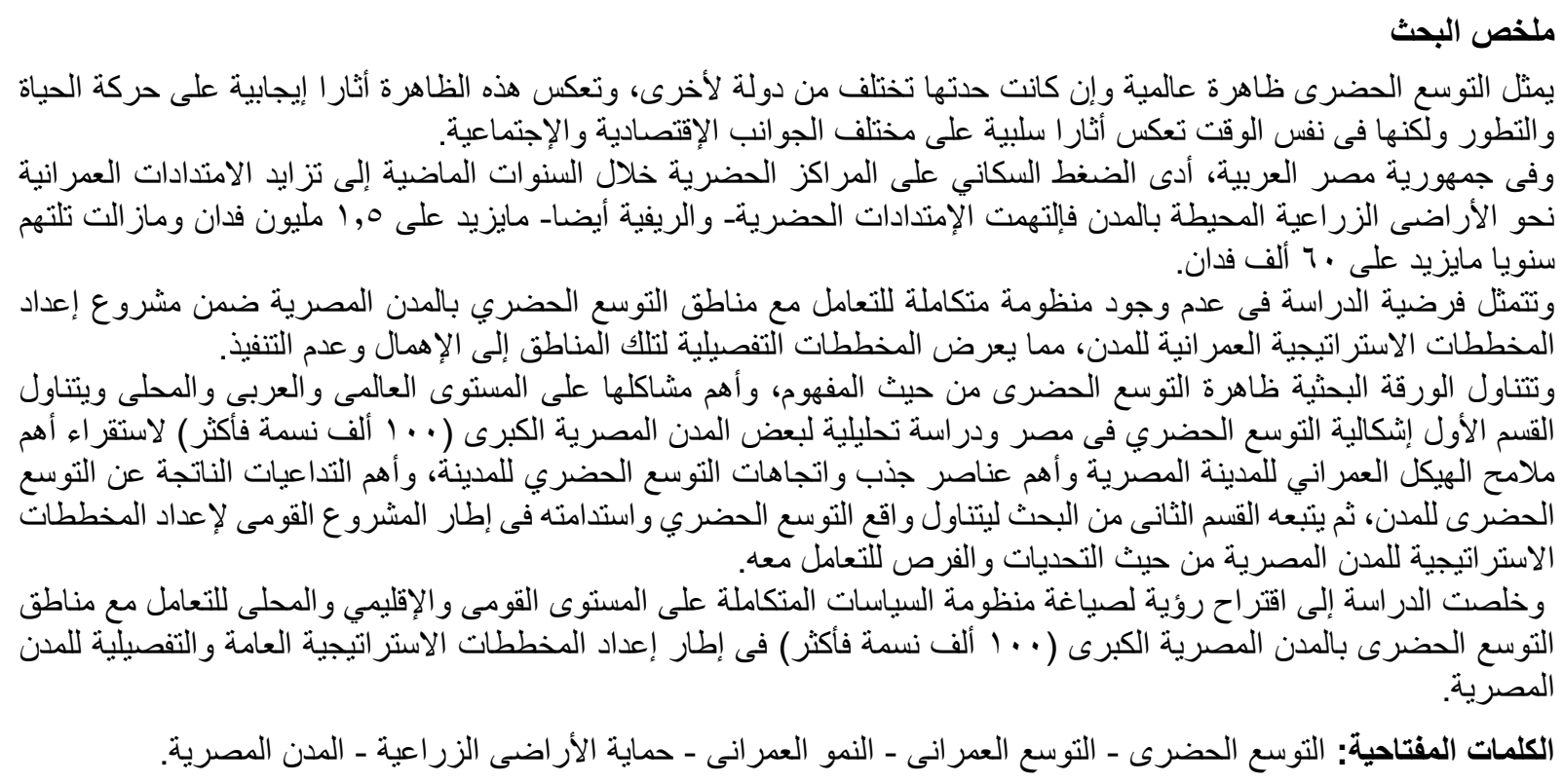




\section{Introduction}

The phenomenon of urban sprawl of cities has emerged to existence due to increased urbanization, despite its differences from one era to another. The urban sprawl is not limited to a group of countries, but it is considered a general situation in all countries.

There are several natural and human factors which contributed in the sprawl phenomenon. There are plenty of ways to define urban sprawl. Although it is hard to give an exact definition about what it actually is, I would like to find a general idea in order to get a conceptual understanding towards this definition.

The phenomenon of urbanization is considered as one of the features of social change that characterized the twentieth century in most of the developed and developing countries. Such changes have affected the individuals and societies in different ways [1].The phenomenon of cities growth is steadily increasing, so the urban population growth rate exceeds the population growth rate [2].

Herper and Gottman defined the urban sprawl process by spread and extension outside the borders of the city without adhering to the limits of the areas where this process has occurred [3].

The urban sprawl is known as continuous increase in the population, whether in planned or unplanned housing, which increases the demand of agricultural land, which creates environmental imbalance [4].

Several studies revealed that urbanization in cities of developing countries is happening in a quantitative rather than a qualitative manner; as there is increasing urban population without a real transformation in lifestyle and behavioural patterns that is associated with life in the cities which is knows as Urbanism [5].

Between 2000 and 2030, the world's urban population is expected to increase by $72 \%$, while the built-up areas of cities of 100,000 people or more could increase by $175 \%$. In the developing countries, cities of 100,000 or more are expected to triple their built-up land area to $600,000 \mathrm{~km} 2$ in the first three decades of this century. Cities in developed countries expand at an even faster rate per resident, despite their smaller population size and lower rate of population growth. They will increase their built-up land area by 2.5 times between 2000 and 2030. At that point, they will occupy some $500,000 \mathrm{~km} 2[6]$.

The Arab region contains the oldest civilizations in the world, as well as, one of the most urbanized regions too. The total population in Arab countries reached about 357 million people in 2010, including $56 \%$ of the urban population; however, these rates will continue to grow, so as to reach approximately 646 million by 2050, including $68 \%$ of urban population.

Additionally, Arab countries recorded a population growth in the cities in 2010, which exceeded four times the growth rates recorded in 1970. In addition, these rates will grow more than the double during the period between 2010 and 2050. It was observed emergence most of the growth operations that have been recorded up to the present in the areas surrounding large cities of the Arab countries, in spite of the medium and secondary cities recorded faster growth rates at present [7].

Development projects and programs in the Arab world failed to achieve their goals and plans that were set to reduce the phenomenon of expansion of cities for many reasons, including [8]:

- The increasing population growth of cities, due to the natural increase in birth rates, low mortality rates, the ongoing migration from the countryside or international immigration, so cities are growing significantly in a short period and large cities get larger. 
- Centralization of urban functions and loss of medium and small cities and decrease its importance so they fail to perform their role in urban development.

- Lack of organizational and administrative structures to attract qualified people and make the administrative organization incapable of solving the growth problems.

- Lack of clear policies for the use of land within cities and they are affected by the interests of powerful economic groups.

- Absence of cooperation, coordination and integration in the programs carried out by various administrative and economic organizations.

- Failure to follow a clear policy in the recruitment of scientific experiences to work in different areas of the country.

"The urban Egyptian Growth rates did not only exceeds its counterparts in the developed countries during the urban revolution in the eighteenth and nineteenth century, but also exceeded the rates of the developing countries itself. For example, during the period between 1950 and 1990, the cities of the developed countries have doubled only once from 450 million to 900 million, while the cities of the developing countries have increased four times from 285 million to 1.15 billion, and the Egyptian cities have increased during the same period four times and a half from 6.4 million to 27.00 million"[9].

\section{Part I The urban sprawl of the Large Egyptian cities}

\subsection{The problem of urban sprawl}

Egyptian cities constituted the centres for non-agricultural activities such as trade, as well as, for administrative, religious and military institutions that were required for the emergence of the regions, then the country. These urban settlements has begun on the sides of the River Nile and its branches, because it was the major artery for transport, it has contributed, more than any other factor, to link these urban settlements with each other and with the capitals of provinces and the National Capital.

- "Whereas, there was a population explosion in the last fifty years of the twentieth century, also there was "an urban explosion". Cities have extended in every direction and swept on its way all the attempts of guidance or containment. This extension was planned only in few areas. Residential and non-residential activities were mixed randomly, which ultimately led to the urban and architectural deformation of the modern Egyptian city. The rivers, railways and regional roads represent the determinants of urban growth in the valley and the delta cities, but soon it extended in the direction of "least resistance" towards the agricultural lands which surround the cities, so the urban and rural sprawl devoured more than 1.5 million acres and still devour 60 thousand acres per year. This sprawl also moved towards the desert parts of the cities such as Cairo. The sprawl has radial or ring shape in most cities of the valley and Delta, and has linear shape in some other cities, such as Alexandria, Port Said and Aswan. It has increased during the second half of the twentieth century four times the urban built-up area of the city."[10].

There are factors other than the population growth that led to the urban sprawl, the most important of which is the state policy by the development of new residential districts in, or near, agricultural lands, also the financial factor which tempts the agricultural land owners to use these lands for non-agricultural purposes. Also, social factors play a prominent role through the desire of some urban residents to live in suburbs of the city, so they transfer some agricultural land to residential land only without the benefit of it in agriculture [11].

- At the beginning of the twentieth century in 1907, the number of large cities (more than 100 thousand people) was only two cities, Cairo and Alexandria; and in the middle of the 
century, the number of large cities rose to be 7 cities, then rose to be 15 in 1960, 20 in 1976 and 27 in 1996; as well as, in the population census of 2006 reached 44 city. Cities began to enlarge leading to accumulation of the population, where in the period between $1907-2006$, the number of cities (less than 25,000) increased from 17 to 68 cities, and the number of medium-sized cities (25,000-100,000 people) from 4 to 121 cities in census of 2006.

\subsection{Methodology}

In this part of the study, the most important features of the Urban Structure of Egyptian city will be discussed, as well as, the most important attraction factors of urban sprawl and its trends, and the most important consequences resulting from the urban sprawl of the cities.

The study methodology is based on selecting the Large Egyptian cities (more than 100 thousand people) and excluding cities of millions due to its privacy and limitations (4 cities), where the number of cities in this case are 40 cities that represent $17.2 \%$ of total Egyptian cities, and its total population amounted 9.4 million people, $30.6 \%$ of total urban population of Egypt (census 2006).Table (1) refers to the number of population distribution of Egyptian cities (census 2006).

Table (1) The number and population distribution of Egyptian cities (census 2006)

\begin{tabular}{|c|c|c|c|c|}
\hline $\begin{array}{c}\text { Categories of cities } \\
\text { (1000 people) }\end{array}$ & $\begin{array}{c}\text { Total } \\
\text { cities }\end{array}$ & $\%$ & $\begin{array}{c}\text { The total urban population in } \\
\text { Categories (people) }\end{array}$ & $\%$ \\
\hline Cities of Million & 4 & 1.7 & 14530009 & 46.3 \\
\hline $500-1000$ & 3 & 1.3 & 2064175 & 6.6 \\
\hline $250-500$ & 10 & 4.3 & 3482380 & 11.1 \\
\hline $100-250$ & 27 & 11.6 & 4038091 & 12.9 \\
\hline $50-100$ & 56 & 24.0 & 3903087 & 12.4 \\
\hline $25-50$ & 65 & 27.9 & 2468619 & 7.9 \\
\hline $10-25$ & 45 & 19.3 & 806267 & 2.6 \\
\hline$<10$ & 23 & 9.9 & 78297 & 0.2 \\
\hline Total & 233 & 100 & 31370925 & 100 \\
\hline
\end{tabular}

Source: Researcher- From final results of Central Agency for Public Mobilization and Statistics -2009.

The study based on selecting a sample of five cities (see Figure (1)) that represent the case study of the cities in that category in particular and the Egyptian city in general, in accordance with the following criteria:

- Governorates capitals (19 cities of more than 100 thousand people).

- The geographical representation of Egypt (Lower Egypt - Upper Egypt), excluding the capitals of some of desert governorates like Arish, Kharga and Hurghada in that category in census 2006.

- The preparation studies of general and detailed strategic plans of these cities.

The five cities (selected case study sample) are three cities of Lower Egypt (Zagazig in Al Sharqia Governorate, Shebein El Kawm in Munufiyya Governorate, and Damanhour in Beheira Governorate), and two cities in Upper Egypt (Fayoum city in Fayoum Governorate, Qena city in Qena Governorate). It will discuss the features and characteristics of the Urban Structure of these cities. The case study sample is represented in three main points as follows:

- The most important features of urban structure of the city (including distribution of land uses, building heights, building situations, building construction and urban pattern), and the gross and net population density.

- The most important attraction elements of urban sprawl and its trends in the city. 
- The most important consequences of urban sprawl of the city.

\subsection{Analytical study of the case study cities}

\subsubsection{The most important features of the Urban Structure}

The most important features and characteristics of the Urban Structure of Large Egyptian cities (more than 100 thousand people), case study cities, table (2), are identified as follows:

- The urban built-up area in cities is ranging from 2012 - 3230 acres with an average of 2366 acres, with per capita rate between $27.0-49.0 \mathrm{~m}^{2}$ ( average $41.6 \mathrm{~m}^{2}$ ), which is relatively a good rate.

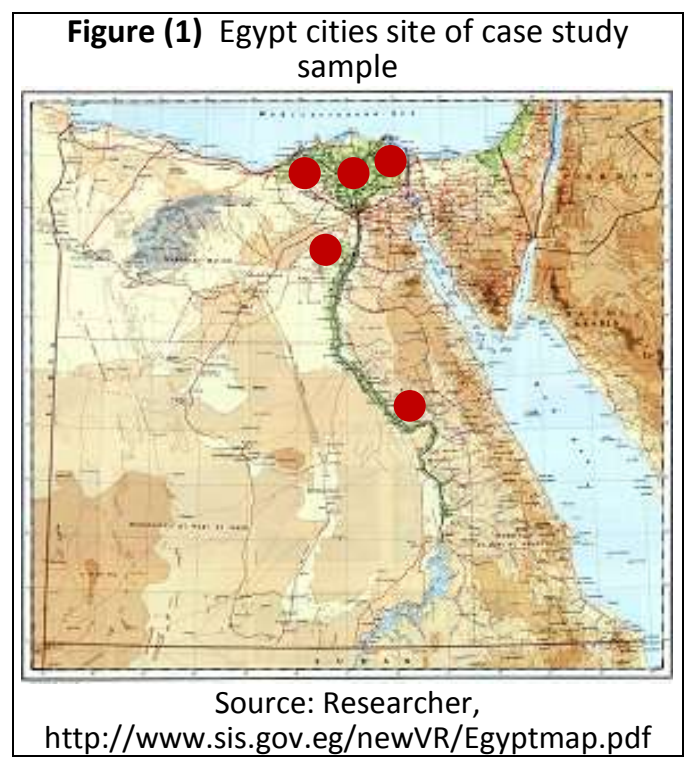

- By analysis of land use budget for these cities, it was clear that residential uses rate is between $33.3-40.7 \%$ with an average of $40.7 \%$ of total urban built-up area of the city which is considered acceptable compared to similar Egyptian cities, this is due to several reasons, including high rate of road network, urban spaces, agricultural pockets and regional uses of the city. However, it ranges between $63.3-87.0 \%$, and with an average $75.3 \%$ of total builtup area, and the public services area is between $7.2-11.7 \%$, with an average of $9.8 \%$, while the industrial activities is between $0.7-6.4 \%$, with an average $3.4 \%$, and regional uses is between $4.5-8.9 \%$, with an average $6.3 \%$, as well as, roads and general spaces of the city is between $19.1-34.1 \%$, with an average $28.1 \%$ of total urban built-up area of the city. The general features of land use of the case study cities- figure (2)- are characterized by the following:

- Lack of a specific pattern of land use distribution for different parts of the city, particularly commercial use.

- Concentration of the main and regional services at the entrance of cities and the peripheral parts.

- Emergence of slum areas, particularly in the last four decades of the city's growth, and lack of urban control.

- Presence of some of the inappropriate (non-urban) uses such as cemeteries, prison, slaughterhouse, etc. in distinguished locations in the old city, which decreases the value of land, especially the city centre close to service areas.

- Existence of the Nile and main canals as functional axis which passes in the city centre, links between the two parts of the main city, exploits parts of it as park and provides open green areas.

- The relative rise in the roads network area and spaces in the city.

- For the built-up area of the city is between 790 - 1483 acres with an average 1146 acres, ranging between 38.8 - 64.3\%, and with an average $48.4 \%$ of the total urban built-up area of the city.

- The building heights in the city, are mostly low and medium, ranging between one and two floor by $26.7-45.3 \%$, and with an average $38.7 \%$ of the total building area of the city, which generally spread in the old areas and in areas that take rural character, that were separate in the form of small rural communities before they enter the cordon of the city. Medium-rise buildings are ranging between 3-5 floors by $41.5-64.9 \%$, and with an average 
49.5\% of the total area of the city buildings. The high-rise buildings (more than 5 floors) and the medium-rise buildings are spread in most regions of the sprawl in different parts of the city and on the main roads.

- The situation of buildings in the city, the buildings area with good situation ranges between $33.8-86.7 \%$, with an average $59.7 \%$ of the total area of the city buildings, and the buildings with medium situation are between $13.4-49.6 \%$, and an average of $33.8 \%$ of the total area of the city buildings, while bad buildings area ranging between $4.7-22.0 \%$, and an average of $11.7 \%$ of the total area of the city buildings, which are concentrated in the old area of the city and in villages adjacent to the urban built-up area of the city that has rural nature, and on the margins of the city, while good buildings are concentrated in the areas of modern sprawl.

Table (2) Features of the urban structure of Large Egyptian cities(case study cities)

\begin{tabular}{|c|c|c|c|c|c|c|c|}
\hline \multicolumn{3}{|c|}{ City } & Zagazig & $\begin{array}{l}\text { Shebein El } \\
\text { Kawm }\end{array}$ & Damanhour & Fayoum & Sohag \\
\hline \multicolumn{3}{|c|}{ Governorate } & Al Sharqia & Menoufia & Beheira & Fayoum & Sohag \\
\hline \multicolumn{3}{|c|}{ Geographical location } & \multicolumn{3}{|c|}{ Lower Egypt } & \multicolumn{2}{|c|}{ Upper Egypt } \\
\hline \multicolumn{3}{|c|}{ The population in census 2006 (people)* } & 302840 & 177112 & 244043 & 315940 & 193168 \\
\hline \multicolumn{3}{|c|}{ Total urban built-up area(acres) } & 3229.79 & 2012.0 & 2304.1 & 2035.0 & 2251.85 \\
\hline \multicolumn{3}{|c|}{$\begin{array}{l}\text { Per capita average in urban built-up } \\
\qquad \text { area( } \mathrm{m}^{2} / \text { person) }\end{array}$} & 44.79 & 47.71 & 39.65 & 27.05 & 48.96 \\
\hline \multirow{3}{*}{$\begin{array}{c}\text { Urban } \\
\text { growth } \\
\text { (1986- } \\
2006)\end{array}$} & \multicolumn{2}{|c|}{$\begin{array}{c}\text { Urban built-up area in } 1986 \\
\text { (acres) }\end{array}$} & 2106.38 & 788.6 & 1661 & 1670.62 & 1963.32 \\
\hline & \multicolumn{2}{|c|}{ The growth rate (acre/year) } & 56.17 & 61.17 & 32.16 & 18.22 & 14.43 \\
\hline & \multicolumn{2}{|c|}{ Size growth } & 1.53 & 2.55 & 1.39 & 1.22 & 1.15 \\
\hline \multirow{7}{*}{$\begin{array}{c}\text { Land } \\
\text { uses } \\
\text { (urban } \\
\text { built-up } \\
\text { area \%) }\end{array}$} & \multicolumn{2}{|l|}{ Housing } & 39.22 & 33.29 & 40.76 & 39.10 & 37.4 \\
\hline & \multicolumn{2}{|l|}{ Public services } & 7.24 & 11.67 & 9.67 & 11.1 & 9.43 \\
\hline & \multicolumn{2}{|l|}{ Industrial activities } & 2.29 & 6.4 & 0.74 & 1.51 & 6.15 \\
\hline & \multicolumn{2}{|c|}{ Space land \& agricultural pockets } & 10.75 & 14.91 & 8.01 & 7.51 & 10.67 \\
\hline & \multicolumn{2}{|c|}{ Regional activities } & 4.54 & 8.83 & 4.97 & 8.91 & 4.50 \\
\hline & \multicolumn{2}{|l|}{ Others } & 5.67 & 5.77 & 1.72 & 3.85 & 2.86 \\
\hline & \multicolumn{2}{|c|}{ Roads and public spaces } & 30.29 & 19.14 & 34.12 & 28.01 & 28.99 \\
\hline \multirow{2}{*}{$\begin{array}{c}\text { built-up } \\
\text { area }\end{array}$} & \multicolumn{2}{|c|}{ The area (acres) } & 1456.2 & 885.84 & 1482.6 & 789.99 & 1117.0 \\
\hline & \multicolumn{2}{|c|}{ \%Total urban built-up area } & 45.09 & 44.03 & 64.35 & 38.82 & 49.6 \\
\hline \multirow{3}{*}{$\begin{array}{l}\text { Building } \\
\text { heights }\end{array}$} & 1-2 Floor & \multirow{3}{*}{$\%$} & 26.67 & 33.46 & 43.14 & 45.30 & 45.10 \\
\hline & 3-5 Floor & & 64.91 & 44.49 & 41.47 & 5002 & 46.91 \\
\hline & More than 5 Floor & & 8.42 & 22.04 & 15.39 & 4.68 & 7.99 \\
\hline \multirow{3}{*}{$\begin{array}{l}\text { Buildings } \\
\text { situations }\end{array}$} & Good & \multirow{3}{*}{$\%$} & 86.66 & 56.38 & 67.8 & 54.63 & 33.80 \\
\hline & Medium & & 13.39 & 34.95 & 26.29 & 44.6 & 49.57 \\
\hline & Bad & & 0.44 & 8.67 & 5.91 & 0.77 & 16.62 \\
\hline \multirow{3}{*}{$\begin{array}{l}\text { Building } \\
\text { constructio } \\
\text { n style }\end{array}$} & Structural & \multirow{3}{*}{$\%$} & 87.26 & 50.50 & 62.99 & 66.24 & 73.91 \\
\hline & Carrying walls & & 11.46 & 47.07 & 36.99 & 33.74 & 24.9 \\
\hline & Mud / Adobe & & 1.27 & 2.43 & 0.02 & 0.02 & 1.19 \\
\hline \multirow{2}{*}{$\begin{array}{c}\text { Populatio } \\
\text { n density } \\
\text { (person / } \\
\text { acre) }\end{array}$} & \multicolumn{2}{|c|}{$\begin{array}{l}\text { gross (Population / urban built-up } \\
\text { area) }\end{array}$} & 94 & 88 & 106 & 155 & 86 \\
\hline & Net (population / residenti & rea) & 239 & 264 & 260 & 397 & 229 \\
\hline
\end{tabular}

* Central Agency for Public Mobilization and Statistics, General Census of Population and installations in 2006. Source: Researcher, from data reports of preparation general strategic plan for Egyptian cities project - General Organization For Physical planning, 2009.

- For the construction method of buildings in the city, structural buildings in the city ranging between $50.5-87.2 \%$, with an average of $68.2 \%$ of the total building area of the city. The percentage of buildings which are built-up by adobe ranges between $0.02-2.4 \%$ with an 
average of $1.0 \%$ of the total building area of the city, but buildings built-up by bearing walls ranging between $24.9-47.0 \%$, with an average of $30.8 \%$ of the total buildings area of the city, due to the availability of red brick at cheap prices as a result of earthmoving work and brick kilns in the governorate.

-The urban pattern of cities was found complex and did not belong to the main planning trends for urban cities, so they are not in the form of grid, linear or central cities, but it has a multi-pattern of different types. The agricultural areas in the urban sprawl areas of the city have a great impact on this conflict which was the obvious feature of the urban fabric. As a result of economic factors and the varying level of the population in this regard, the construction materials, building heights and land use have varied. As we move to the periphery, the urban growth was more modern and has new urban patterns in buildings. The roads have had a role in attracting this urbanization, so the urbanization seems to be in line with the modern streets and roads that enter and exit the city, so they act as arms extending from the original urban fabric.

- Finally, the average gross population density, it ranges between 86-155 persons / acre, with an average of 106 persons / acre, which is consider low density due to the relatively large empty land, regional services, and road network in the city, but the net population density (population / residential area) is relatively high, ranging between 229-397 person / acre, with an average of 278 persons / acre.

\subsubsection{Trends and attraction factors of urban sprawl}

Through the study of development stages of urban growth for the Large Egyptian cities, case study cities, which are located in the middle of fertile agricultural land like any other town in the Delta and the Nile Valley, we can conclude that the Egyptian city grew in all directions, so urban built-up area overlaps the surrounding agricultural land, where there are planted areas in many places within the urban built-up area, which threaten agriculture directly. It is noticeable that this urban sprawl had been remarkable only during the last three decades, where urban growth rate of the case study cities during the period 1986 - 2006, ranged between 14.4 - 61.1 acre / year, with average of 36.4 acre / year, and the increase of the urban built-up area ranged between 1.1 - 2.6 times with an average of 1.6 times during the same time period, which was relatively higher in Lower Egypt cities compared to the Upper Egypt cities, as shown in table (2).

We can identify the most important factors to attract urban sprawl in case study cities as follows:

- Administrative adjustments: such as converting Shebein El Kawm from an ordinary city to the capital. Its impact appears in the development and growth of the city in all directions, because this was followed by the establishment and concentration of administrative services, as well as the establishment of various health, educational and cultural services, thus attracts the population from all aspects. In addition to, the inclusion of some villages such as Mitkhakan and Kafr Meselha to Shebein El Kawm city as an expansion of its vital urban field, so buildings extended to the agricultural land that was separating those villages and Shebein El Kawm city leading to an overlap of the construction of the city with these villages in a short period.

- Urban and natural axes: the urban axes are represented in contact and transportation including roads and railways such as Cairo- Alexandria agricultural road, CairoAlexandria railway, and Bahr Shebein. It is considered an important factor for connecting the city to other cities economically and socially. As well as military and 
security areas and cemeteries. The natural axes are represented in waterways such as the Nile River, canals, main drains, flood outlet in Qena, contour lines (in Shibein El Kawm), and agricultural land surrounding the urban built-up area. The urban and natural axes have played an important role in guiding urban development of the Egyptian city, leading to new activities and uses of lands whether residential, commercial or administrative.

- Regional services and new development projects: such as the university, stadium, hospital, spinning \& weaving factory... etc, which have a clear impact on attracting employment, revive economic life in the city and helped to attract and grow urbanization, because it attracts many of the activities that integrate with it, rises the value of the land adjacent to it, and increased traffic density on the roads leading to it. Urban growth rates and trends can be divided into three categories as follows:

a-Rapid urban growth axes: this growth is represented in the direction of the concentration of regional services in general, such as: Educational services (universities, technical schools), some administrative services (electricity administration - traffic department), some recreational services (stadium and social club), and around the axes of the regional transportation and main waterways (river, canal).

b-Medium urban growth axes: represented in the central areas of the city in the presence of land division projects, government housing projects or some local services (mosque, shops, schools, ... etc).

c- Low urban growth axes: represented in the direction of villages which are semiconnected with the city or around the ancient tombs of the city, as well as, the presence of the industrial zone. These sprawls lack importance and usually take random character. And the urban pattern of these sprawls is grid and semi-urban in the periphery of the city.

\subsubsection{Consequences of urban sprawl}

The random extensions in the periphery of case study cities and the continuous increase in the population densities associated with the rapid urban growth aggravated the problems faced by these urban centers to the degree that temporary solutions and partial repair failed to eradicate its causes in Egypt during the past three decades, which had a range of consequences, including:

- Rapid urban growth and encroachment on agricultural land surrounding the city that was represented in:

- Unplanned random urban sprawl, that caused suffering from a decline in the supply of utilities, health and education services, and the lack of correlation of its urban structure with other main urban parts of the city, which was able to accommodate times the number of the population, if it was pre-planned.

- Overlap with the surrounding villages of the city, as a result of its rapid growth and overlap of the rural pattern with the urban pattern due to the existence of some rural areas within the urban built-up area (Dar El Ramad, El Alawi and Qahafa in Fayoum). These zones are characterized by internal contrast between it and its neighbouring zones in terms of the nature of the urban pattern, which could be called random rural zones. The majority of buildings in these zones consist of one or two floors which are built by adobe stones in a deteriorated state which is a reflection of the social and economic conditions and the way of life in these zones. 
- Waste and Pressure on public facilities. The unplanned housing areas get basic facilities like water and electricity, through the illegal use of the existing networks in the planned areas; leading to high wastage of water and electricity networks, which needs double the cost compared to the cost of delivered services to the planned areas.

- The unplanned construction is a real estate wealth. In the absence of law that regulates these assets, this wealth is considered a restricted capital from participating in the economic activity.

- Weak capacity to provide emergency services in the unplanned housing areas; due to the narrow streets and the cohesion of the buildings that cause difficult access to the ambulance, fire and security services.

- Deformation of the civilized face of the Egyptian society; as a result of the mixing of urban and architectural patterns between urban and rural areas "[12].

- Regional land use interfering with urban built-up area: such as the prison in Fayoum, cemeteries, slaughterhouse, barns, stores or military areas, or its presence in strategic areas on the main axes and adjacent to the residential areas, increasing the environmental problems (pollution and noise - reducing the efficiency of traffic in the city).

- Industrial uses within the urban built-up area: This leads to unwanted environmental pollution.

- Pollution of uncovered waterways and the surrounding areas and using them to get rid of waste and garbage.

- Breakthrough of urban built-up area by the regional roads, railways or waterways, dividing the city into two parts that caused a lot of traffic problems (traffic nodes) and environmental problems (noise and pollution).

\section{Part II Between the reality of the urban sprawl and its sustainability in the Large Egyptian cities}

The second part discuss the government efforts dealing with the urban sprawl in the framework of the national project preparation for the general and detailed strategic plans of the Egyptian cities, and analyze the reality of urban sprawl in terms of challenges and opportunities to deal with. It concluded a vision to formulate integrated policies to deal with the urban sprawl areas in Egyptian cities.

\subsection{Government efforts to deal with the urban sprawl}

The government has launched the national project for the preparation of the general and detailed strategic plans of the Egyptian cities (225 cities) [13], through "participatory planning" methodology, to achieve the competitiveness of the city and formulate its future vision .The most important outputs of the first phase of the project include: the proposed urban border of the city until 2027, identify activities and needs (housing, public services, economic activities, infrastructure) to the expected number of population in the target year, and localization of activities and priority projects in the various sectors, in addition to descriptive supplements of those activities and projects, the cost, participant and the institutional work plan. The second phase comes considering outputs of the general strategic plan as the basic information to prepare detailed urban plans for the development of sprawl areas, and the land adjacent to the slum areas in the periphery of the city within the approved urban border of the city until 2027- figure (3), to ensure its growth in a planned shape instead 
of its random expansion, including (land use, housing, services, activities, the proposed projects, road network, development controls, planning and building requirements).

\subsection{Analysis of the challenges and opportunities of the urban sprawl planning}

We can address the challenges and opportunities of the urban sprawl planning in case study cities- as follows:

\section{First: The challenges}

The challenges dealing with the urban sprawl planning of the case study cities, lie in the following considerations:

- Multiple and overlapping laws that lack integration with respect to urban management of the city and do not encourage land use for suitable public purposes and services.

- Lack of coordination between the various authorities which are responsible for urban management, lack of domestic financial resources, and the weakness of the capacities and qualifications of workers in local administration.

- Lack of information and accurate inventory of public and private properties (Tenure) of lands.

- Refrain from land and buildings registration because of its lengthy procedures and high registration fees, and this leads to lack of proof of ownership at the local administration for the urban management of the city.

- The long duration required for the adoption of the plans and budgets which confirms the necessity of activating participation of the society, the private sector, together with the non-governmental and community organizations and the reliance on self-potentials.

- The lack of large areas of land of public and government ownership due to fragmenting the ownership into small areas.

- Inconsistency in the distribution of current public services with the urban built-up area growth in all directions randomly.

- The lack of most existing services to cover current needs, as well as the future needs of the city.

- The existence of slums areas which are characterized by bad status of the building, insufficient maintenance and the lack of various services and facilities (water, drainage, services ...), which led to its deterioration and increasing poverty, unemployment and illiteracy.

\section{Second: The opportunities}

Through preparation of detailed plans of future urban sprawl areas of the city within the proposed urban border of case study cities of the target year of 2027. These opportunities can be referred to as follows:

- Moral and financial readiness of citizens to contribute to the development of expansion of urban sprawl areas.

- The ability to support businessmen and investors and motivate self-efforts for financing the projects of public services.

- Providing some governmental land (Al-Awqaf lands,...etc) in areas that allow settlement of future needs of public service.

- Providing some lands in large areas of private property, which can be negotiated for use in public services. 
- Trying to set higher rates of public services for the urban sprawl and expansion areas than the current existing rates.

- Using the waterways (River Nile, main canals) and waterfronts as entertainment and tourist areas.

- Transmitting undesirable uses; such as cemeteries, prisons and heavy factories outside the built-up area to desert lands or near new cities and exploiting these areas, after evacuating them, as open areas, services areas, or residential areas to accommodate the population growth.

- Existence of new urban communities as a desert extension adjacent to the governorate that can play an important role in attracting population growth and reduce the population pressure on the urban structures in rural and urban areas.

\subsection{Proposed Vision to deal with the urban sprawl areas}

In the framework of preparation of detailed urban plans for developing expansion and urban sprawl areas, which represents one of the main outputs of the national project preparation of general and detailed strategic plans of Egyptian cities, a proposed vision can be set for the system of integrated policies on national, regional and local level to deal with the urban sprawl areas in case study cities - Table No. (3). This system aims at assuring the growth of these areas in a planned way instead of random expansion, and contributes positively in the sustainability of these areas and achieving its social and economic aims. This prevents the neglect and lack of implementation of the detailed plans of these areas. It depends on five main pillars (legislation, financing, community participation, the land, administrative and institutional framework), and requires the existence of an effective agreement among them, as follows:

- The First Pillar: Legislation: Review the validity of laws, legislation, and the current regulations and updating them in order to fulfill financial, administrative and planning aspects for dealing with lands and projects of urban sprawl areas. This also helps in the development of the areas adjacent to the random peripheral areas specified in the general and detailed strategic plans.

- The Second Pillar: Financing: Establishment of real estate development company (Public money) in partnership with the governorate whereas the company possesses big financial and executive capabilities. Another alternative is a stock exchange company or a subsidiary company of a bank, in a way that the bank gets a percentage of the projects to sell and collect its price on long term installments. Such a company makes the integrated urban development of expansion areas in the certified urban border of city.

- The Third Pillar: Community Participation: To identify the needs for land according to the specific citizen standards. Starting from the right of suitable house by possession guaranteed by law, providing the appropriate living conditions as well as providing public services and facilities within appropriate cost limits, taking into consideration sustainability of these needs.

- The Fourth Pillar: Land: The availability of lands owned by the state in expansion and sprawl areas in the Egyptian cities or the new urban communities in desert areas adjacent to the valley and Delta. This can help to absorb a large part of the population increase. Gathering small properties by expropriation for public benefit, after compensating the previous owners, and combining these properties in one area in order to prepare an integrated plan for the development of these areas. In addition to establishment of information system specialized for the expansion areas to secure the tenure properly and can be used to monitor the land 
distribution. This can provide a base for the tax system on properties, take the necessary measures to apply an electronic system for land management providing information about real estate and their transactions via internet. Together with preparing technically qualified personnel at the engineering departments to manage the urban development process.

- The Fifth Pillar: Administrative and Institutional Framework: By strengthening the frameworks of local, central governmental and non-governmental institutions (Private sector, NGOs) to ensure the implementation of urban sprawl plans. This can be achieved by supporting the local administrations with its requirements from trained staff and means that enable it to achieve the requirements of urban sprawl in the certified plan. Together with the coordination between the local, regional and central involved agencies to work in an integrated and compatible framework.

Table (3) The Proposed system of integrated policies to deal with the urban sprawl areas in case study cities at the national, regional and local levels.

\begin{tabular}{|c|c|c|c|}
\hline Pillars & National Level & Regional Level & Local Level \\
\hline$\frac{.}{\frac{c}{0}}$ & $\begin{array}{l}\text { - Activation of current law or } \\
\text { the issuance of a unified } \\
\text { legislation to organize the } \\
\text { financial, administrative and } \\
\text { planning aspects of } \\
\text { management system of } \\
\text { expansion and urban sprawl } \\
\text { areas in order to ensure its } \\
\text { quality and continuity. }\end{array}$ & $\begin{array}{l}\text { - Achievement of future national } \\
\text { trends and strategies for providing all } \\
\text { kinds of housing and public services at } \\
\text { all levels. }\end{array}$ & $\begin{array}{l}\text { - Recognition of customary } \\
\text { tenure system within a legal } \\
\text { framework which ensures } \\
\text { ownership and possession. } \\
\text { - Enabling the municipalities } \\
\text { to own lands in the certified } \\
\text { urban border of city. }\end{array}$ \\
\hline : & $\begin{array}{l}\text { - Investments mobilization } \\
\text { and raising the efficiency of } \\
\text { allocation of financial resources } \\
\text { to implement the development } \\
\text { projects. } \\
\text { - Encouragement of private } \\
\text { sector to invest in the } \\
\text { establishment of residential } \\
\text { buildings and public services, } \\
\text { then renting them to service } \\
\text { agencies for a limited period } \\
\text { with a rent that guarantees high } \\
\text { returns. After that, its possession } \\
\text { is reverted to the state. }\end{array}$ & $\begin{array}{l}\text { - Propose procedures and } \\
\text { mechanisms which determine } \\
\text { methods and resources of funding } \\
\text { and financial support of urban sprawl } \\
\text { projects in accordance with specific } \\
\text { priorities and certain funding and } \\
\text { executive timetables in a regional and } \\
\text { local integrated framework. } \\
\text { - Phased development; the real } \\
\text { estate company recovers the costs of } \\
\text { development and extending the } \\
\text { public utilities. }\end{array}$ & $\begin{array}{l}\text { - Funding housing and public } \\
\text { services projects through } \\
\text { donation or international and } \\
\text { local grants. } \\
\text { - Charging fees against } \\
\text { reservation of lands allocated to } \\
\text { public services without } \\
\text { development to prevent } \\
\text { commercial speculation upon it. } \\
\text { - Activating competition in all } \\
\text { kinds of public services to reduce } \\
\text { the cost of providing these } \\
\text { services }\end{array}$ \\
\hline 몸 & $\begin{array}{l}\text { - Ownership deprivation and } \\
\text { resale at the market price policy: } \\
\text { According to law no. (10) in1990, } \\
\text { and construction law no.(119) } \\
\text { in2008 for urban expansion } \\
\text { lands of the city strategic plan. } \\
\text { These lands can be used for } \\
\text { public benefit purposes after } \\
\text { paying an adequate price, by the } \\
\text { executive authorities which will } \\
\text { establish infrastructure of these } \\
\text { lands including roads } \\
\text { construction and supply services, } \\
\text { then selling the land at the } \\
\text { market price after dividing it. }\end{array}$ & $\begin{array}{l}\text { - Land Purchase Policy: The } \\
\text { proposed real estate development } \\
\text { company buys some or all urban } \\
\text { sprawl lands at the urban border } \\
\text { certified by the city. } \\
\text { - Exchange of Land in return of } \\
\text { land Policy: By compensation of } \\
\text { aggrieved land owners who swaped } \\
\text { their land for public benefit, with } \\
\text { another land equal or bigger in area, } \\
\text { according to their market value. } \\
\text { - Improvement allowance policy: } \\
\text { By collecting price difference from } \\
\text { owners of buildings and land whose } \\
\text { values increased due to preparation } \\
\text { of detailed plans of urban sprawl } \\
\text { areas, this money are used in } \\
\text { providing public services and utilities. }\end{array}$ & $\begin{array}{l}\text { - Land Availability Policy: } \\
\text { Providing land owned by the state } \\
\text { at expansion and urban sprawl } \\
\text { areas or throughout grants and } \\
\text { donations of citizens, } \\
\text { associations, trade unions and } \\
\text { civil society organizations. } \\
\text { - The full removal, re-division } \\
\text { and resettlement Policy: It } \\
\text { depends on the idea of removal } \\
\text { of old and ruined buildings, then } \\
\text { re-planning the area and } \\
\text { exploiting it in urban } \\
\text { development with the possibility } \\
\text { of resettlement of the same } \\
\text { residents at the area. }\end{array}$ \\
\hline
\end{tabular}


Follow up,Table (3) The Proposed system of integrated policies to deal with the urban sprawl areas in case study cities at the national, regional and local levels.

\begin{tabular}{|c|c|c|c|}
\hline Pillars & National Level & Regional Level & Local Level \\
\hline 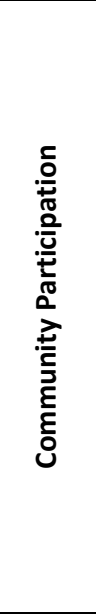 & $\begin{array}{l}\text { - Providing suitable housing } \\
\text { by the state for everyone } \\
\text { together with encouragement of } \\
\text { community participation in } \\
\text { housing support for poor and } \\
\text { low-income people and } \\
\text { providing public services. }\end{array}$ & $\begin{array}{l}\text { - Possibility of partnership of land } \\
\text { owner of urban sprawl areas with } \\
\text { proposed real estate development } \\
\text { company in the development projects } \\
\text { and fulfillment of educational and } \\
\text { health public services on their lands in } \\
\text { accordance with technical } \\
\text { specifications set by concerned } \\
\text { authorities. } \\
\text { - Development of adequate } \\
\text { awareness of citizens towards the } \\
\text { importance of commitment to the } \\
\text { requirements of management of } \\
\text { urban sprawl areas and } \\
\text { accomplishment of its immediate and } \\
\text { deferred aims. }\end{array}$ & $\begin{array}{l}\text { - Direct community } \\
\text { participation in the preparation } \\
\text { of general and detailed strategic } \\
\text { plans of the urban sprawl areas. } \\
\text { Together with participation in } \\
\text { making decisions and specifying } \\
\text { roles and responsibilities of civil } \\
\text { society individuals and } \\
\text { institutions in the achievement of } \\
\text { these plans. }\end{array}$ \\
\hline 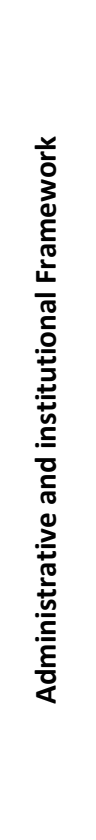 & $\begin{array}{l}\text { - Prepare a national strategy } \\
\text { of housing and services, } \\
\text { integrated with development } \\
\text { plans of existent cities and new } \\
\text { urban communities. } \\
\text { - Adjust and strengthen } \\
\text { central institutions structures, } \\
\text { together with the local } \\
\text { governmental and non- } \\
\text { governmental institutions } \\
\text { (Private sector, civil associations) } \\
\text { in order to accomplish the urban } \\
\text { sprawl plans. } \\
\text { - Institutional support and } \\
\text { good training of local } \\
\text { administration. } \\
\text { - The freedom of data and } \\
\text { information transfer and } \\
\text { knowledge partnership. } \\
\text { - Cooperation } \\
\text { coordination with authorities } \\
\text { granting projects and services. }\end{array}$ & $\begin{array}{l}\text { - Providing the technical support, } \\
\text { capacity building and setting an } \\
\text { update plan of geographical data and } \\
\text { its local requirements responsible for } \\
\text { sustainable urban development in } \\
\text { cities. } \\
\text { - Set procedures to allow } \\
\text { following, evaluating and controlling } \\
\text { phases of urban sprawl, which usually } \\
\text { depends on administrative system by } \\
\text { result, which depends on specifying a } \\
\text { logic frame to resources, activities, } \\
\text { outputs and targets. } \\
\text { - Achievement of coordination } \\
\text { required among the local, regional } \\
\text { and central concerned authorities to } \\
\text { work in a framework of integration } \\
\text { and compatibility. }\end{array}$ & $\begin{array}{l}\text { - Application of decentralized } \\
\text { system in the management of } \\
\text { expansion and urban sprawl, } \\
\text { specifying companies, } \\
\text { administrative structures and } \\
\text { institutions responsible for the } \\
\text { implementation and follow-up. } \\
\text { - Application of planning and } \\
\text { building conditions of urban } \\
\text { sprawl and requirements for } \\
\text { building services design. } \\
\text { - Support local authorities by } \\
\text { trained key staff and means } \\
\text { which enable them to follow-up } \\
\text { and achieve requirements of } \\
\text { urban sprawl management in } \\
\text { different stages at the certified } \\
\text { plan. }\end{array}$ \\
\hline
\end{tabular}

Source: Researcher

\section{Conclusion}

This research discussed a basic theoretical issue which is the urban sprawl phenomenon in terms of the concept and its main problems at the global, Arab and local levels. In the first part, an analytical study was done for some large Egyptian cities (more than 100 thousand people) to detect the main features of urban structure of the Egyptian city, the main attraction factors, trends and consequences of urban sprawl of the Egyptian city. Next, the second part dealt with the urban sprawl reality and its sustainability under the framework of national project to prepare the strategic plans of Egyptian cities in terms of challenges and opportunities. The research proposed a vision for the integrated policy system at the national, regional and local levels to deal with the urban sprawl areas in the case study cities.

We believe that as long as urban population growth is an unavoidable reality in Egypt in the future; there would be a difficulty in facing the urban sprawl expansions of Large Egyptian cities because of the difficulty of influence on the demographic and land variables in 
the short term due to the natural, environmental, economic and social challenges which are imposed by the settlement circumstances in the desert areas, and that dealing with urban sprawl expansions in the large Egyptian cities in the absence of integration between various sectorial plans may increase the negative effects of focusing the investment and development plans in certain cities exclusively.

Moreover, the absence of integrated policies dealing with urban sprawl at the national, regional and local levels, which determine the needs, in the light of available resources, to achieve sustainable development and upgrade the urban environment and quality of its life. Furthermore, the magnitude of planning efforts needed to address the problem of urban sprawl and urban expansions in the large Egyptian cities throughout decreasing population pressure and transferring the future overflow of its population to wherever economic profitable resources are available, on its borders or faraway in the middle of the desert.

In addition, planning the urban expansions inside the proposed urban border in the strategic plans by the activation of supply and demand forces on the urbanism. This can be achieved by continuous development of urban space, prediction of trends for the urban demand, encouragement of settlement in it and organization of the building inside the developed border. All this increases the opportunity to attract various investments and service projects which reflects on development at the local and regional levels, with a set of planning regulations and conditions to maintain the development and prevent and speculation.

Consequently, some recommendations can be suggested: First, it's important to review terms of reference (TOR) to prepare the strategic plan of Egyptian cities by the General Organization For Physical planning to ensure the application of the proposed system of integrated policies to deal with the urban sprawl areas in large Egyptian cities(more than 100 thousand people)that relies on five pillars which are legislation, financing, community participation, land, administrative and institutional structure. The strategic plans outputs provide comprehensive, accurate and real indicators about urban sprawl in the Egyptian cities to supply the decision and development policy makers in the state to contribute in the preparation and development of the national urban policies.

Second, the necessity of community and citizen participation in the preparation of the strategic plans of cities regarding decisions involving urban sprawl areas inside the urban border because these decisions concern characteristics of housing environment and job opportunities in these areas in a direct way.

The third recommendation is the necessity of the local authorities to have decentralized finance through the development of its local resources such as the establishment of a real estate company to allow the development and progress of urban sprawl in a method that is integrated with the surrounding environment characteristics and local society needs.

Fourth recommendation ensures the necessity of cities growth and organization of their roles (as centers for population attraction and economic activities) throughout comprehensive sectorial policies and programs in the frame of local, regional and national strategic plans.

Last recommendation is the necessity of supporting the governmental programs directed to the service of low- income population, especially for small areas regarding the organization of housing lands and their provision in the strategic plan of each city.

Finally, renewal and innovation are necessary. New models in the development of urban sprawl areas should serve the local environment, fulfill its needs and improve it 
according to future visions of cities, as well as preparation of guidelines for principles, standards and planning and designing rates in this field. In this respect, it is important to provide e-governmental tools including data related to existing plans for land division, areas and buildings regulations and land possession records which facilitate the procedures of granting the building license. Together with land price information and the use of digital technologies and modern means such as the technology of Geographic Information Systems (G.I.S) in setting the detailed plans of urban sprawl areas to contribute positively in solving many urban troubles.

\section{References}

[1] Richard V.C. and David ,R, why Cities Change,G.Arand , and unwin Australia, 1982.P.35.

[2] Lowry J.H. City Growth, Edward Arnold ,London,1979 P.I.

[3] Harper and Gottman, (The Human Geography) john willey and sons press-New York, U.S.A , 1967, p.23.

[4] F.Kenneth Hare. (Climate Variations Drought and Desertification) Word Metretogical Organization (WMO), No. 630, Geneva, Switzerland, 1985, p. 340.

[5] Wirth, L. "Urbanization as a Way of Life ". In: Fava, S, Urbanism in World Perspective. New York: Thomas Cornell Company, 1986.

[6] United Nations Population Fund-State of World Population 2007-Unleashing the Potential of Urban Growth, P.45-47 Available on:_https://www.unfpa.org/sites/default/files/pubpdf/695 filename sowp2007 eng.pdf. (Site accessed 5 October 2015).

[7]United Nations Human Settlements Programme (UN-Habitat) 2012, The State of Arab Cities 2012 Challenges of Urban Transition, Second Edition - December2012, P.viii, Available on:http://www.unhabitat.org.jo/en/inp/Upload/134359 OptiENGLISH StateofArabCities Edited 25 12 2012.pdf. (Site accessed 5 October 2015).

[8] Kamona, HidarAbd-Al-Razek, (Doctor), Civilization Policies of Arab World, General Cultural Affairs Centre, Culture and Information Ministry, Baghdad 1990-P.175.

[9]Rageh, Abu Zaid, Egyptian Urbanization- Monitor of Developments in Egypt Lands Urbanization in the Late Twentieth Century and Exploration of Future Pathways up till 2020- The Academic LibraryEgypt-2007, pp.29-30.

[10]Abu ZeidRageh, Egyptian Urbanization, op. Cit., PP. 192 -195.

[11]Abd Al-Kader, Hasan and Mansur Hamdi Abu Ali, the Geographic Basic of Problem of Desertification, Sunrise Centre for Publishing and Distribution, Amman, 1989- p. no.1, P.90.

[12] Democratic National Party, The Working Paper of Conservation of Agricultural land and Urban Growth Management in Egypt, Egypt, 2004.

[13]The General Organization For Physical planning (GOPP) -Terms of reference (TOR) of preparation the General and Detailed Strategic plan of the Egyptian City-2006-Available on :http://www.gopp.gov.eg/upload/projects/TOR Cities.pdf.(Site accessed 20 September 2013).

\section{Other references}

[14]Central Agency for Public Mobilization and StatisticsAvailable on : http://www.capmas.gov.eg/ [15]State information service,http://www.sis.gov.eg/newVR/Egyptmap.pdf

[16]General Organization For Physical planning, Egyptian Cities Strategic Plan Project,http://gopp.gov.eg/ 


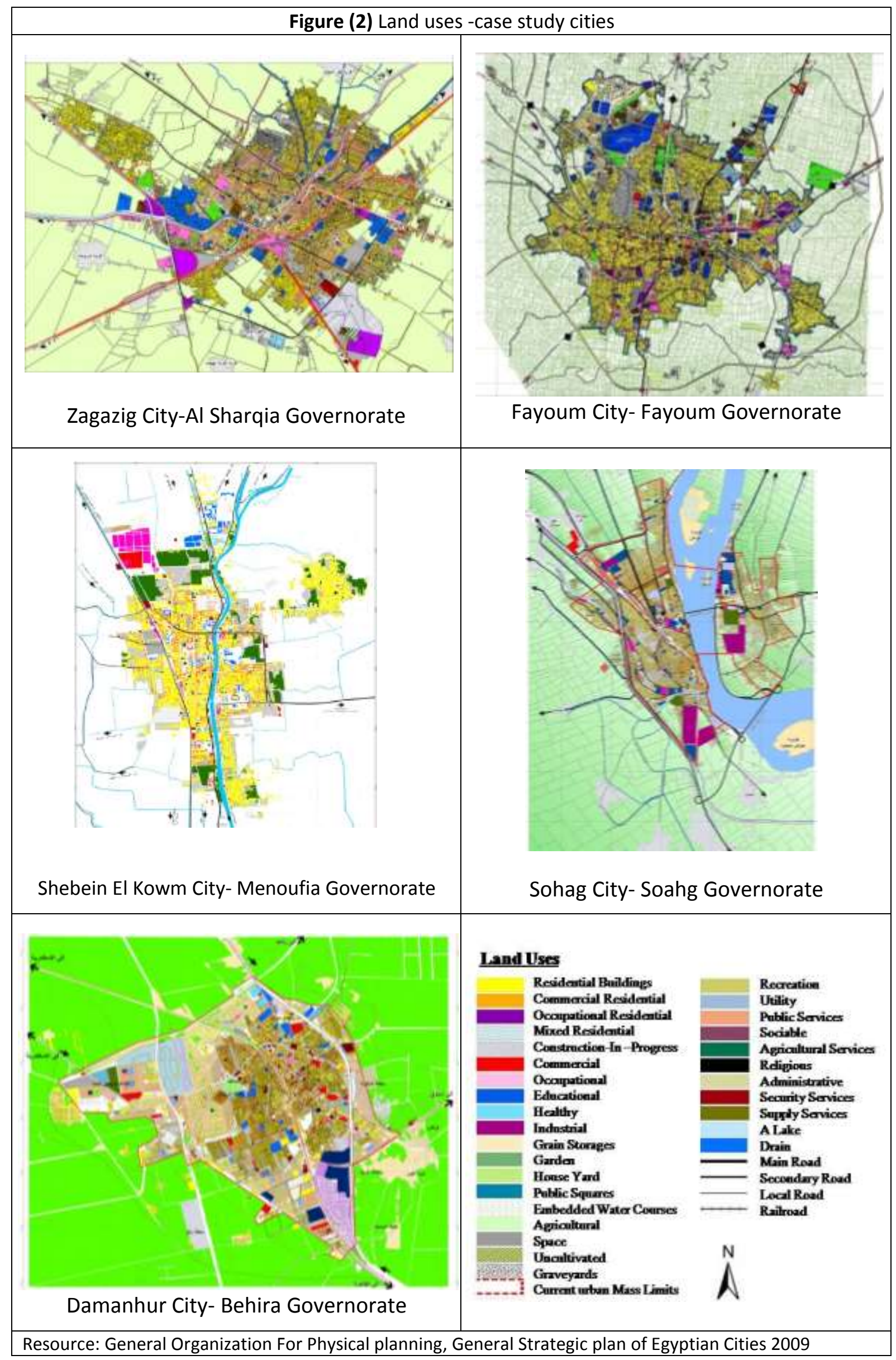




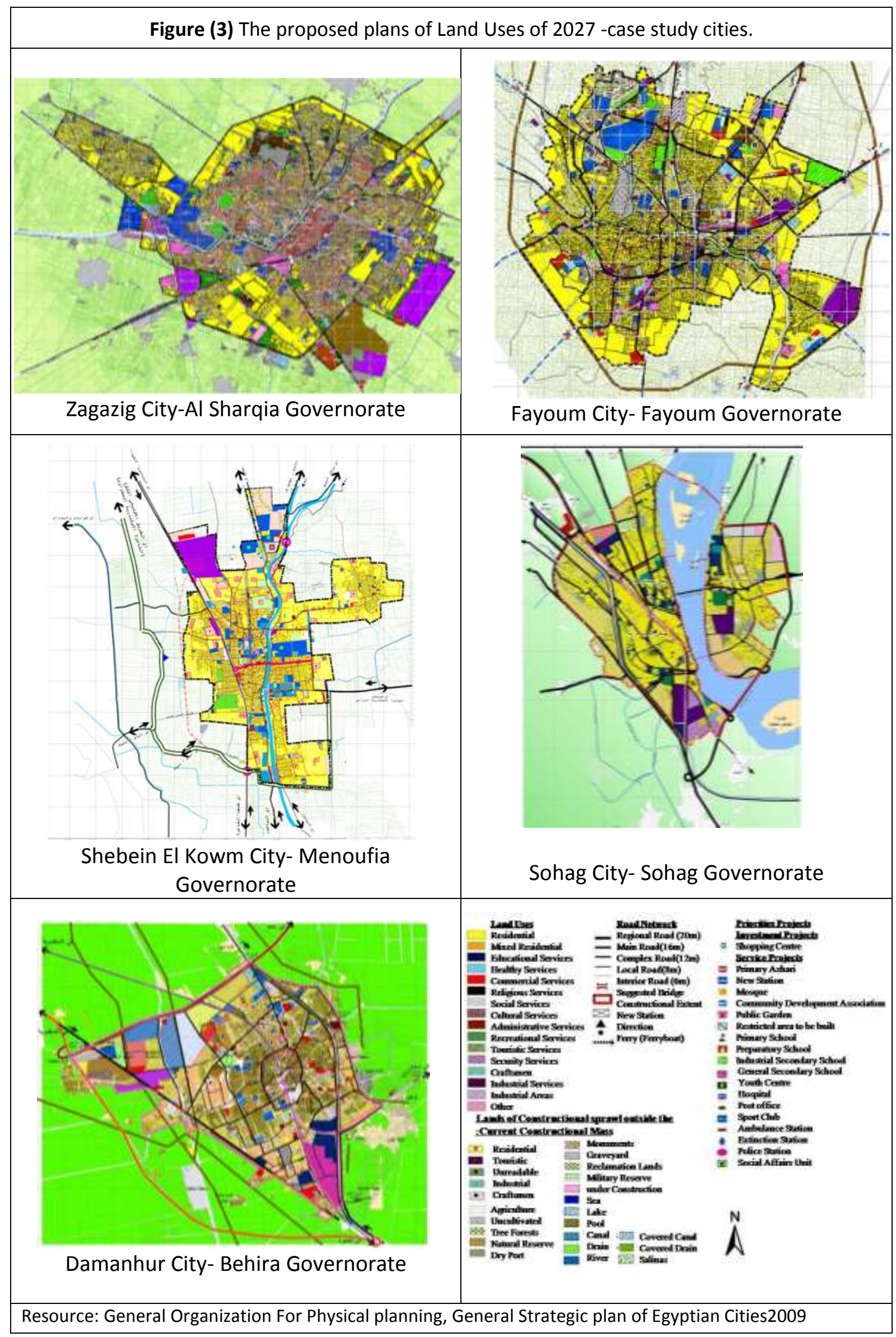

